УДК 37 (477) (092)

DOI: $10.35619 /$ iiu.v1i10.172

\begin{abstract}
Кочубей Тетяна
доктор педагогічних наук, професор, професор кафедри соціальної педагогіки та соціальної роботи Уманського державного педагогічного університету імені Павла Тичини, м. Умань, Україна ORCID: 0000-0002-9104-8442 e-mail: udpu_tania@ukr.net.
\end{abstract}

Ткачук Лариса кандидат педагогічних наук, доцент, доцент кафедри педагогіки та освітнього менеджменту Уманського державного педагогічного університету імені Павла Тичини, м. Умань, Україна ORCID: 0000-0003-3337-2540 e-mail: larysa.tkachuk.2011@gmail.com

\title{
ІДЕЯ РАДОСТІ ПІЗНАННЯ У ПЕДАГОГІЧНІЙ СПАДЩИНІ В. СУХОМЛИНСЬКОГО: НАУКОВО-МЕТОДИЧНИЙ АСПЕКТ
}

Анотація. У статті доведено, що В. Сухомлинський у системі своїх педагогічних поглядів грунтовно розкрив сутнісний зміст ідеї радості пізнання та послідовно реалізував іï у навчально-пізнавальній практиці Павлиської середньої школи. Стверджено, що у педагогічних творах і досвіді В. Сухомлинського ідея радості пізнання виступає необхідною умовою творчого саморозвитку, морального самовдосконалення, ефективним засобом формування в учнів наукового світогляду. Продемонстровано тлумачення видатним педагогом дефініції «радість пізнання» як світоглядної категорії, складного інтегрованого утворення та комплексу стійких морально-інтелектуальних якостей особистості школяра. Представлено основні науково-методичні засади ідеї радості пізнання школярів у творчій спадщині видатного педагога. Наголошено, що у положеннях педагогічної системи В. Сухомлинського радість пізнання виступає і як спеціальний об'єкт утвердження, i як опосередкований складник успішної реалізації завдань розвитку і саморозвитку дитячої особистості. Доведено, що ідея радості пізнання школярів у Василя Сухомлинського грунтувалася на оптимізмі, вірі в людину, іiі добре начало. Акцентовано на створенні розвивального та виховального середовища Павлиської школи, на нововведеннях, започаткованих у Павлиші, які створювали екологічні умови розвитку, навчання і виховання дитини. Наголошено на співзвучності ідей видатного педагога та концептуальних положень Нової української школи.

Ключові слова: радість пізнання, педагогічна спадщина В. Сухомлинського, розвивальне середовище, екологічні освітні умови, Нова українська школа.

Постановка проблеми. Принциповою особливістю модернізації сучасної шкільної освіти $є$ суттєві зміни у методичному забезпеченні освітнього процесу, новому розумінні його результатів. Основним завданням сучасного закладу освіти $\epsilon$ «організація такого освітнього середовища, що сприятиме вільному розвитку творчої особистості дитини» (Міністерство освіти і науки України, 2018), оскільки без його розв'язання не можна розраховувати на подальше зростання інтелектуального потенціалу суспільства, що є необхідною умовою прогресу України: іiі економіки, науки, техніки тощо. Одним із дієвих шляхів вирішення цієї проблеми є утвердження у шкільної молоді радості пізнання. 
У цьому контексті актуальним $\epsilon$ досвід видатного педагога Василя Олександровича Сухомлинського, який грунтовно розкрив сутнісний зміст ідеї радості пізнання та послідовно реалізував її в освітній практиці Павлиської середньої школи. Він, по-суті, представив модель школи, якої потребує сучасне суспільство: вона була сприятливим екологічним середовищем дитинства, середовищем щасливого життя дитини, середовищем радості пізнання: себе, оточуючого світу, надбань світової інтелектуальної думки. Саме тому вивчення та узагальнення досвіду видатного педагога в цілому та у зазначеному аспекті $є$ надзвичайно актуальним для сьогодення.

Аналіз останніх досліджень 3 проблеми. Окремі аспекти педагогічної спадщини В. Сухомлинського стали предметом вивчення науковців як в Україні (М. Антонець, Л. Бондар, І. Бех, А. Богуш, М. Вашуленко, І. Зязюн, Н. Калініченко, В. Кузь, А. Луцюк, Д. Пащенко, О. Петренко, А. Розенберг, О. Савченко, О. Сараєва, О. Сухомлинська та ін..), так і за іiі межами (М. Библюк, М. Богуславський, Е. Гартманн, М. Мухін, В. Риндак, С. Соловейчик, Х. Франгос та ін.).

Здійснюючи аналіз ступеня дослідженості науково-педагогічної спадщини та практичного досвіду В. Сухомлинського у руслі ідеї радості пізнання у школярів, варто, насамперед, відзначити дисертаційне дослідження М. Богуславського «Ідея стимулювання радості пізнання у школярів в педагогічних працях $\mathrm{i}$ досвіді В. О. Сухомлинського» (1986), у якому проаналізовано розвиток теоретичних основ і методики стимулювання радості пізнання у школярів у педагогічній системі В. О. Сухомлинського.

У низці дисертаційних робіт (В. Василенко, М. Дубинка, К. Кривошеєнко, Ю. Новгородська, Г. Сухорукова та ін.) розкрито шляхи вдосконалення В. Сухомлинським організації та змісту навчального процесу та розвиток його ідей у практиці сучасної школи.

Заслуговують на увагу дисертаційні дослідження членів наукової лабораторії «В. О. Сухомлинський і школа XXI століття» Уманського державного педагогічного університету імені Павла Тичини, здійснені під керівництвом академіка В. Кузя Н. Безлюдної «Ідеї розвивального навчання молодших школярів у творчій спадщині В. О. Сухомлинського», Г. Бондаренка «Формування творчої особистості молодшого школяра в педагогічній спадщині В. О. Сухомлинського», В. Кушнір «Провідні гуманістичні ідеї творчої спадщини Я. Корчака у контексті розвитку вітчизняної педагогічної думки», І. Суржикової «Педагогічні ідеї Василя Сухомлинського і Селестена Френе (порівняльний аналіз)», в яких розкрито окремі аспекти ідеї радості пізнання школярів у спадщині видатного педагога. В аспекті піднятої проблеми значний інтерес для цілісного вивчення ідеї радості пізнання у школярів в педагогічній спадщині В. Сухомлинського представляють дисертаційні дослідження Т. Кочубей «Філософія дитинства в педагогічній спадщині В. О. Сухомлинського» (2002), де розкрито сутність та характерні ознаки дитинства, теоретично обгрунтовано ідеї філософії дитинства у педагогічній спадщині В. О. Сухомлинського та Л. Ткачук «Педагогічне забезпечення успіху в навчанні молодших школярів у творчій спадщині В. О. Сухомлинського» (2001), в якому здійснено науковий аналіз теоретикопрактичного досвіду педагогічного забезпечення успіху в навчанні молодших школярів у творчій спадщині В. О. Сухомлинського.

Важливе значення у межах заявленої теми мають праці: «Школа Сухомлинського у Павлиші - погляд крізь призму часу», в якій зазначено, що всебічний розвиток дитини у Павлиській школі здійснювався через «гармонію педагогічних впливів 3 опорою на чітко визначений перелік того, що дитина має знати й уміти в результаті навчання через радість пізнання, радість розумової праці, успіху у навчанні...» (Сухомлинська, 2013 , с. 77); «Гуманізм педагогіки В. О. Сухомлинського» (Мухін, 1994), «Світлий геній Павлиша» (Калініченко, 2018), в яких схарактеризовано педагогічні погляди видатного педагога, досліджено розвиток творчого потенціалу вчителя та педагогічного колективу у Павлиській середній школі, сутність виховального і 
розвивального середовища, яке невтомно формував видатний педагог. У монографії «Дитинство: радість пізнання (за ідеями В. Сухомлинського)» (Кочубей, Ткачук, Безлюдна, 2017) представлено філософське осмислення феномена «дитинство»у педагогічній концепції видатного педагога; висвітлено ідею радості успіху в навчанні учнів початкової школи у теоретичній і практичній діяльності вченого; проаналізовано психофізіологічну основу, зміст, організаційні форми, методично-процесуальне забезпечення розвивального навчання в емпіричному досвіді педагога-новатора.

У силу фрагментарності зазначених робіт, вимагає системного підходу висвітлення питання науково-методичного аспекту ідеї радості пізнання школярів у творчій спадщині В. Сухомлинського у контексті іiі творчого застосування в освітньому просторі Нової української школи.

Мета статті полягає у тому, аби максимально повно здійснити дослідження методичного аспекту ідеї видатного педагога про радість пізнання школярів та ії значення для подальшої модернізації системи освіти в Україні.

Виклад основного матеріалу дослідження. Звертаючись до педагогічної спадщини В. Сухомлинського, без перебільшення можемо стверджувати, що радість пізнання видатний педагог вважав обов'язковою умовою освітнього процесу і його результатом: «Дух радості пізнання - ось та ідейна та інтелектуальна атмосфера, яка повинна зараз панувати у школі» (Сухомлинський, 1968, с. 22). Педагог зазначав, що процес навчання школярів має супроводжуватися тільки позитивними емоціями: радістю нового знання, радістю досягнення «через розвиток у них потреби в пізнанні, цікавості, допитливості» (1977, т. 3, с. 125), адже «без емоційного піднесення неможливий нормальний розвиток клітин дитячого мозку...» $(1977$, т. 3, с. 45). Однак, зауважимо, що Василь Олександрович неодноразово наголошував на тому, що «навчання не можна пристосовувати до радостей, навмисно полегшувати тільки для того, щоб дитині воно не здавалося нудним. Дітей треба поступово готувати до найголовнішої справи всього життя - до серйозної, старанної праці, яка неможлива без напруження думки» (1977, т. 3, с. 112). Педагог стверджував: «Почуття радості доступне лише тому, хто вміє напружувати сили, знає що таке піт і втома», відтак «дитинство не повинно бути постійним святом - якщо немає трудового напруження, що під силу дітям, для дитини залишиться недосяжним і щастя праці» $(1977$, т. 3, c. 239).

У педагогічних творах і досвіді В. Сухомлинського ідея радості пізнання виступає необхідною умовою творчого саморозвитку, морального самовдосконалення, ефективним засобом формування в учнів наукового світогляду. Він написав близько 1500 розповідей для дітей, що стосуються різних сторін розвитку, формування i виховання дитини, пробуджують допитливість, «радість пізнання»; дають уявлення про конкретні чи абстрактні предмети, відображені в словах, діях, в дитячих відчуттях, сприйнятті, уяві; процес пізнання в дитячих відчуттях, сприйнятті, уяві (Сухомлинська, 2002). В. Сухомлинський (1979, т. 3, с. 173) закликав: «Вчитимемо дитину думати, відкриємо перед нею першоджерело думки - навколишній світ. Дамо їй найбільшу людську радість - радість пізнання».

М. Богуславський (1986) зазначає, що видатний педагог тлумачив поняття «радість пізнання» як світоглядну категорію, оскільки «вона стимулює повне й продуктивне оволодіння духовними й матеріальними багатствами життя. Головне, що складає серцевину цього поняття і розкриває його змістову сторону - це єдність раціонального й емоційного, думки і почуття, трудового і духовного начал пізнавальної діяльності учня».

Аналіз педагогічної спадщини В. Сухомлинського, що грунтується на широкому колі друкованих та архівних джерел, в яких узагальнюється теорія i практика розглядуваного питання, дозволяє стверджувати, що «радість пізнання» він розглядав як складне інтегроване утворення, як комплекс стійких морально-інтелектуальних якостей особистості школяра, що обумовлюють позитивну спрямованість мотивів його 
пізнавальної діяльності й забезпечують задоволеність від цілісного процесу пізнання та суспільної значущості його результатів; «як стан, в якому найбільш ефективно відбувається процес інтеріоризації стимулів і виникає збудження випереджуючого типу, тобто така психічна активність, яка, з одного боку, випереджує діяльність, яка ще не здійснюється, а 3 іншого - виступає як спонукання до надання ій тривалого і відносно стабільного характеру, що визначається впливом зовнішнього та внутрішнього стимулювання» (Богуславський, 1986).

Отже, радість пізнання, за В. Сухомлинським, обов'язково має бути індивідуальним набутком кожного учня. Думки видатного педагога щодо вирішення цієї проблеми прямо чи опосередковано висвітлено у надзвичайно широкому діапазоні його праць. Наведемо лише короткий перелік об'єктів здійсненого нами аналізу праць педагога, де розглядається ця проблема: вивчення внутрішнього світу дитини, іiі мотиваційної та потребової сфери; взаємодія об'єктивних та суб'єктивних умов розвитку школярів у процесі пізнавальної діяльності: позитивна емоційна забарвленість пізнавальної діяльності учнів; мислення та розумове виховання учнів; відчуття, сприймання, допитливість, інтерес як дієвий стимул пізнання та радості оволодіння основами наук; відбір змісту шкільної освіти, «Дві програми навчання», індивідуальний підхід до навчання дітей 3 різними навчальними можливостями та різного віку; «важкі» $\mathrm{i}$ обдаровані діти; сутність навчання, організація і методи навчання, оцінювання знань, умінь, навичок дітей; читання книг, дослідницька діяльність і праця як джерела розвитку і саморозвитку учнів тощо.

Опрацювання цих аспектів дає змогу визначити науково-методичні засади ідеї радості пізнання школярів у творчій спадщині В. Сухомлинського. Вони охоплюють такі положення: ідея самоцінності й неповторності, талановитості кожної дитини; всебічне, глибоко продумане вивчення особистості дитини у різних видах діяльності, у взаємозв'язку урочної та позаурочної роботи та іiі вільний розвиток у педагогічно продуманих умовах; організація переживання дітьми нагромадженого досвіду; створення для дитини «радості буття» через виховальне і розвивальне середовище іiі життєдіяльності; організація різних видів активної, особистісно значущої діяльності дітей (колективної й індивідуальної) в урочний і позаурочний час і збагачення іiі яскравими позитивними емоціями; перевага позитивних стимулів i реакцій на поведінку дитини над негативними; погляд на життєдіяльність школярів як на насичений творчими відкриттями процес пізнання та самопізнання; спрямованість діяльності педагогічного колективу на особистісний розвиток і саморозвиток дітей 3 різними навчальними можливостями; цілеспрямована мотивація учнів на досягнення максимального рівня розвитку своїх духовних і навчальних можливостей; поступове оволодіння всіма учнями умінням вчитися на рівні самонавчання та саморозвитку; створення атмосфери успіху; використання праці й природи як джерел особистісного розвитку кожної дитини; гуманізм усіх видів спілкування та співпраці в учнівському колективі; формування почуття власної гідності кожної дитини; довіра й повага до дитячої особистості; пріоритетність моральної й розвивальної функцій в оцінюванні навчальних досягнень кожної дитини; реалізація актуальних і перспективних завдань у школі зусиллями дітей, вчителів, батьків.

У положеннях педагогічної системи В. Сухомлинського, на наш погляд, радість пізнання виступає і як спеціальний об'єкт утвердження, і як опосередкований складник успішної реалізації завдань розвитку і саморозвитку дитячої особистості.

Концептуальний за своєю суттю підхід В. Сухомлинського до теоретичної розробки ідеї радості пізнання гармонійно поєднувався із здійснюваною ним дослідноекспериментальною роботою, яка була складовою частиною організованого із кінця 40-х до кінця 60-х років XX ст. у Павлиській середній школі творчого педагогічного експерименту. Директор та педагогічний колектив школи у пошуках шляхів і засобів утвердження в школярів радості пізнання вирішували завдання: цілеспрямованого i різнопланового формування у дітей бажання вчитися; постановки вчителями всіх 
предметів поточних і перспективних цілей розвитку мислення і творчих здібностей учнів 3 різними навчальними можливостями; досягнення тісного взаємозв'язку мовленнєвої, розумової та трудової діяльності дітей; залучення школярів до дослідницької діяльності; проведення уроків мислення в природі - біля джерел думки; творчі роботи учнів з розвитку мовлення і літературної творчості (складання учнями описів, розповідей, казок); стимулювання інтелектуальних та естетичних почуттів школярів; інноваційний підхід до оцінювання навчальних досягнень учнів тощо (Сухомлинський, 1977, т. 4).

Аналіз педагогічної спадщини В. Сухомлинського у контексті розглядуваного у статті питання дозволяє виокремити складові компоненти творчого стилю діяльності павлиських вчителів: гуманізм, ставлення до дитини як до унікальної особистості, природовідповідність, культуровідповідність, опора на позитивне в дитині, створення ситуації успіху, широке застосування у навчанні й вихованні комплексів стимулів: ідейних, інтелектуально-творчих, пошуково-дослідницьких, естетичних; одухотворення знання, створення «інтелектуального фону школи», особистісна захопленість учителя своїм предметом, що поєднується 3 ентузіазмом у педагогічній діяльності; уміння ставити проблеми, досяжні розумінню та пізнавальним можливостям школярів, здатність вчити їх самостійно і творчо знаходити шляхи вирішення цих проблем; оптимізм стосовно пізнавальних i творчих можливостей вихованців, віра у їхні сили та передача цього стану учням.

Ідея радості пізнання у Василя Сухомлинського грунтувалася на оптимізмі, вірі в людину, їі добре начало. Вона окреслювала критерії «щасливого дитячого життя», на яких базувалася діяльність школи: визнання права дитини на іiі особливість, неповторність та багатовимірність; прийняття дитини такою, якою вона $\epsilon$, 3 iї позитивними i негативними потенціями; вимога не дорікати i зайвий раз не акцентувати уваги на негативних рисах ії характеру; спрямованість освітнього процесу на виховання поваги, пошани, довіри до кожної дитини; утвердження принципів людяності, добра, любові, філософії «серця», збереження здоров'я дитини; формування у дітей потреби виконувати кодекс правил поведінки; створення умов для самореалізації, самовиявлення обдарувань особистості через залучення іiі до різних видів діяльності. Цьому сприяли різні форми організації навчання та виховання дітей і нововведення, започатковані у Павлиші: «Школа радості», «Школа під голубим небом», «Уроки мислення серед природи», «Подорожі до джерела думки», «Уроки в зелених класах», уроки мислення, уроки розвитку мовлення; «вузлики знань», «Книга природи», дві програми навчання (обов'язкова i розширена), «Кімната казки», «Куточок мрії», «Острів чудес», «Хрестоматія з етики для читання учням Павлиської середньої школи», задачник для неуважних, уроки доброти та людяності, десять «не можна», дев'ять «негідних речей», батьківська школа, психологічні комісії та психологічні семінари.

Таким чином, цілісний характер процесу утвердження радості пізнання в школярів у керованій В. Сухомлинським школі забезпечував його повноту й внутрішню єдність, органічну взаємодію з освітньою роботою в цілому і водночас створював сприятливі умови для ефективного й цілеспрямованого впливу на мотиваційну сферу особистості учня, динамізував формування у нього провідних морально-інтелектуальних якостей, які забезпечують становлення й утвердження нового психічного стану його особистості - стан радості пізнання.

Теорія і досвід В. Сухомлинського у галузі розробки аналізованої проблеми органічною частиною ввійшли у сучасну реформовану початкову школу України, яка повністю перейняла підхід видатного педагога до побудови «Школи радості» 3 духом світла, радості пізнання, любові, куди діти поспішають 3 радістю і 3 надією оволодівати знаннями.

Багато змін відбувається нині в освіті: урізноманітнюються методичні підходи, розробляються нові освітні технології, інтегровані курси і варіативні програми. 
Заклади освіти та вчителі мають робити все, аби кожна дитина вже у початковій школі розкрилася наче квітка від мудрості і сердечності тих, хто творить освіту в державі; «дати дітям радість праці, радість успіху в навчанні, пробудити в їхніх серцях почуття гордості, власної гідності - це перша заповідь виховання» (Сухомлинський, 1977, т. 3, c. 164).

Висновки і перспективи подальших розвідок. Глибоке вивчення й філософськопедагогічний аналіз педагогічної спадщини $\mathrm{B}$. Сухомлинського дають змогу стверджувати, що ним була розроблена оригінальна методика, здатна забезпечити перетворення учнівського колективу у дієвий фактор утвердження радості пізнання, яка збагатила педагогічну науку новаторськими ідеями i положеннями, відіграла значну роль у розвитку теорії і практики виховання й навчання дітей.

Перспективи подальших наукових пошуків вбачаємо у дослідженні можливості використання ідеї видатного педагога про утвердження радості пізнання у позакласній та позашкільній виховній роботі. Такого роду дослідження дозволять реалізувати у цілісному і повному вигляді в практиці сучасної освіти ідею В. Сухомлинського про радість пізнання.

\section{СПИСОК ВИКОРИСТАНИХ ДЖЕРЕЛ}

Міністерство освіти і науки України, (2018). Методичні рекомендацї щзодо організації освітнього простору Нової украӥнської школи. [online]. Режим доступу: https://mon.gov.ua/ua/npa/pro-zatverdzhennya-metodichnih-rekomendacij-shodoorganizaciyi osvitnogo-prostoru-novoyi-ukrayinskoyi-shkoli [Дата звернення 01.03.2019].

Богуславский, М. (1986). Идея стимулирования радости познания у школьников в педагогических трудах и опыте B. А. Сухомлинского. Кандидат педагогических наук. Московский государственный педагогический институт.

Кочубей, Т. (2002). Філософія дитинства в педагогічній спадщині B. О. Сухомлинського. Кандидат педагогічних наук. Уманський державний педагогічний університет імені Павла Тичини.

Ткачук, Л. (2002). Педагогічне забезпечення успіху в навчанні молодших школярів у педагогічній спадщині B. О. Сухомлинського. Кандидат педагогічних наук. Уманський державний педагогічний університет імені Павла Тичини.

Сухомлинська, О. (2013). Школа Сухомлинського у Павлиші - погляд крізь призму часу. Київ: Педагогічна думка. 124 с.

Кочубей, Т., Ткачук, Л., Безлюдна, Н. (2017). Дитинство: радість пізнання (за ідеями В. Сухомлинського). Умань: Видавець «Сочінський М. М.». 220 с.

Сухомлинский, В. (1968). Трудность и радость познания: письмо сельской учительнице. Работница. № 9. С. 22 - 23.

Сухомлинський, В. (1977). Серце віддаю дітям. Вибрані твори в 5-ти т. Т. 3. Київ: Радянська школа. С. 7 - 279.

Сухомлинська, О. (2002). Філософія для дітей як педагогічна проблема. Режим доступу:

http://library.udpu.org.ua/library_files/psuh_pedagog_probl_silsk_shkolu/2/visnuk_1.pdf (дата звернення 18.06.2019).

Сухомлинський, В. (1977). Павлиська середня школа. Вибрані твори в 5-ти т. Т. 4. Київ: Радянська школа. С. 7 - 390.

\section{REFERENCES}

Ministerstvo osvity i nauky Ukrainy, (2018). Metodychni rekomendatsii shchodo orhanizatsii osvitnoho prostoru Novoi ukrainskoi shkoly [Guidelines for the Organization of the Educational Space of the New Ukrainian School]. [online]. Rezhym dostupu: https://mon.gov.ua/ua/npa/pro-zatverdzhennya-metodichnih-rekomendacij-shodoorganizaciyi-osvitnogo-prostoru-novoyi-ukrayinskoyi-shkoli [Data zvernennia 01.03. 2019]. (in Ukrainian) 
Boguslavskiy, M. (1986). Ideya stimulirovaniya radosti poznaniya $u$ shkolnikov $v$ pedagogicheskikh trudakh i opyte V. A. Sukhomlinskogo [The Idea of Stimulating the Pupils Joy of Cognition in V. Sukhomlinskiy's Pedagogical Works and Experience]. Kandidat pedagogicheskikh nauk. Moskovskiy gosudarstvennyi pedagogicheskiy institut. (in Russian)

Kochubei, T. (2002). Filosofiia dytynstva $v$ pedahohichnii spadshyni $V . \quad O$. Sukhomlynskoho [The Philosophy of Childhood in V. O.Sukhomlynskyi Pedagogical Heritage]. Kandydat pedahohichnykh nauk. Umanskyi derzhavnyi pedahohichnyi universytet imeni Pavla Tychyny]. (in Ukrainian)

Tkachuk, L. (2002). Pedahohichne zabezpechennia uspikhu v navchanni molodshykh shkoliariv u pedahohichnii spadshchyni V. O. Sukhomlynskoho [Pedagogical Assurance of Success in Teaching Younger Pupils in V. Sukhomlynskyi's Pedagogical Heritage]. Kandydat pedahohichnykh nauk. Umanskyi derzhavnyi pedahohichnyi universytet imeni Pavla Tychyny]. (in Ukrainian)

Sukhomlynska, O. (2013). Shkola Sukhomlynskoho u Pavlyshi - pohlyad kriz pryzmu chasu [Sukhomlynskyi School in Pavlysh - a View through the Lens of Time]. Kyiv: Pedahohichna dumka. 124 s. (in Ukrainian)

Kochubei, T., Tkachuk, L. \& Bezliudna, N. (2017). Dytynstvo: radist piznannia (za ideiamy V. Sukhomlynskoho) [Childhood: the Joy of Cognition (according to V. Sukhomlynskyi Ideas)]. Uman: Vydavets "Sochinskyi M. M.”. 220 s.]. (in Ukrainian)

Sukhomlinskiy, V. (1968). Trudnost i radost poznaniya: pismo selskoj uchitelnitsy [Difficulty and Joy of Knowledge: A Letter to a Rural Teacher]. Rabotnitsa. No 9. S. 22 23. (in Russian)

Sukhomlynskyi, V. (1977). Sertse viddaiu ditiam [I Give My Heart to the Children]. Vybrani tvory v 5-ty t. T. 3. Kyiv: Radianska shkola. S. 7-279]. (in Ukrainian)

Sukhomlynska, O. (2002). Filosofiia dlia ditei yak pedahohichna problema [Philosophy for Children as a Pedagogical Problem] [online]. Rezhym dostupu: http://library.udpu.org.ua/library_files/psuh_pedagog_probl_silsk_shkolu/2/visnuk_1.pdf (data ostannoho zvernennia 18.06.2019). (in Ukrainian)

Sukhmlynskyi, V. (1977). Pavlyska serednia shkola [Pavlysh Secondary School]. Vybrani tvory v 5-ty t. T. 4. Kyiv: Radianska shkola. S. 7-390. (in Ukrainian)

\title{
THE IDEA OF THE JOY OF COGNITION IN V. SUKHOMLYNSKYI'S PEDAGOGICAL HERITAGE: SCIENTIFIC AND METHODOLOGICAL ASPECT
}

\author{
Tetiana Kochubei \\ Doctor of Sciences (in Pedagogy), \\ Professor, Professor at the Department of \\ Social Pedagogy and Social Work, \\ Uman Pavlo Tychyna State Pedagogical University, \\ Uman, Ukraine \\ ORCID: 0000-0002-9104-8442 \\ e-mail: udpu_tania@ukr.net
}

Larysa Tkachuk

$\mathrm{PhD}$ (Pedagogy), Associated Professor, Associated Professor at the Department of Pedagogy and Educational Management, Uman Pavlo Tychyna State Pedagogical University,

Uman, Ukraine

ORCID: 0000-0003-3337-2540

e-mail: larysa.tkachuk.2011@gmail.com

\footnotetext{
Abstract. In the article it has been proved that V. Sukhomlynskyi thoroughly revealed the essential content of the idea of the joy of cognition in the system of his pedagogical views
} 
and consistently implemented it in the educational and cognitive practice of Pavlysh secondary school. It has been argued that in V. Sukhomlynskyi's pedagogical works the idea of the joy of cognition is a necessary condition for creative self-development, moral selfperfection, an effective means of shaping pupils' scientific outlook. Teacher's interpretation of the joy of cognition has been demonstrated as a worldview category, as a complex integrated formation and a complex of stable moral and intellectual qualities of the pupil's personality. The basic scientific and methodological foundations of the idea of pupils' joy of cognition in the creative heritage of an outstanding teacher have been presented: the idea of self-worth and uniqueness, talent of each child; comprehensive study of the child's personality and his/her free development in pedagogically thought-out conditions; organization of getting by children accumulated experience; organization of different kinds of active activity of children and enrichment with its bright positive emotions; a view of pupils' learning activities as a process of cognition and self-discovery rich with creative discoveries; orientation of pedagogical staff activity on personal development and selfdevelopment of children with different educational opportunities; the use of labor and nature as sources of personal development for each child; affirmation of the dignity of each child; trust and respect for the child's personality; prioritizing moral and developmental functions in evaluating each child's educational achievement. It has been emphasized that in the provisions of V. Sukhomlynskyi's pedagogical system, the joy of cognition acts as both a special object of approval and as an indirect component of the successful realization of the child's personality development and self-development tasks. It is proved that the idea of Vasyl Sukhomlynskyi's joy of cognition was based on optimism, faith in man. It has been emphasized on Pavlysh school development environment, innovations started in Pavlysh: "Joy School", "Blue Sky School", "Nature Thinking Lessons", psychological commissions and psychological seminars, etc. that created environmental conditions for the child's development, her education and upbringing. The outstanding teacher's ideas and conceptual provisions of the New Ukrainian School have been accentuated.

Keywords: joy of cognition, V. Sukhomlynskyi's pedagogical heritage, development environment, ecological educational conditions, New Ukrainian School.

Стаття надійшла до редакиії 02.09.2019 p. 